\title{
Is Solar Powered Irrigation Technology Sustainable Option for Groundwater Irrigation Management in Nepal's Terai?
}

\author{
Bhesh Raj Thapa ${ }^{1, *}$, Baburam Paudel ${ }^{2}$, Rabindra Karki ${ }^{3}$, Manita Raut ${ }^{1}$, Michael Scobie ${ }^{4}$, Erik Schmidt ${ }^{4}$ \\ ${ }^{1}$ International Water Management Institute (IWMI), Nepal Office, Durbar Tole, Pulchowk-3, Lalitpur, G. P. O. Box \\ 8975, EPC 416, Kathmandu, Nepal \\ ${ }^{2}$ Renewable World, Nepal Office, Lalitpur, Nepal \\ ${ }^{3}$ International Development Enterprises, Lalitpur, Nepal \\ ${ }^{4}$ University of Southern Queensland, Toowoomba, Australia \\ Corresponding Email: bthapa.ioe@gmail.com, B.thapa@cgiar.org
}

\begin{abstract}
:
The most densely populated Terai Plains of Nepal with poor access to irrigation water in the dry season resulting the food insecure community. Several initiatives have been carried out to improve the irrigation facilities by extracting the ground water resources using solar, diesel, and grid operated electric pumps. Sustainability of all those initiatives and identifying the most viable solution is always in question. In this context, this study attempts to assess the cost effectiveness of these pumping technologies considering life cycle cost (LCC) in the context of Terai region of Nepal. Observation, Key informant interview (KII), in depth interview, and Focus Group Discussion (FGD) were conducted in 14 different sample sites to assess the performance of technology, life cycle cost and unit water cost (UWC) in different capacity utilization factors (CUFs), farmer's perception, affordability, and profitability. The characteristics considered while selecting the sample sites were of size of pumping system, date of installation, beneficiary households, grid situation, solar vendor, implementing organization, major application of solar pumped water, and major cost associated. Low utilization factor of solar pumps has been observed in almost all sites. Solar pumps become expensive than diesel pump, if it is operated at less than $45 \%$ CUF. Grid operated electric pumps are found cost effective than diesel and solar, if gridline is near to pump site. If solar pump is operated at $10 \%$ CUF, the per unit water cost is NPR. 24.4, and the cost is reduced to NPR. 2.83 , if it is operated at $90 \%$ CUF. Solar pumps need to be operated at least 700 hours per year to compete with diesel pump. The payback period for solar pump was calculated considering cost per unit of water at three different price NRs 5.51, 7.92, and 10 and found as 6.97, 4.1, and 3.14 year respectively for $70 \%$ utilization factor. High upfront cost of solar powered system, poor access to financing and technology seems to be hindering factor to popularize the system. Effective supply chain network, easy access to repairing service, introduction of cash crops instead of traditional crops, promotion of micro irrigation techniques, better access to finance and technology, operation of solar pump at high CUF through grid connection to sell/buy surplus/deficit energy, and subsidized price of solar operated irrigation technology could help to become solar powered techniques as sustainable option in near future to popularize and easy operation for irrigation water management in Terai Region of Nepal. However, Government needs to formulate and implement the policy for utilization and overexploitation of groundwater resources with expansion of solar, diesel, and electric operated pumps in near future to make groundwater resources sustainable.
\end{abstract}

Keywords: Cost Effectiveness of Groundwater Pumping, Groundwater Pumping, Solar Pumped Irrigation System

\section{Introduction}

Majority of farmers are engaged in subsistence farming due to low land holding capacity, fragmented plots, lack of access to irrigation facilities and heavily dependent on monsoon rainfall. Which need to be into commercial farming with the provision of irrigation facility. The productivity of irrigated land is approximately three times greater than that of rain-fed land [1]. Government of Nepal $(\mathrm{GoN})$ has introduced favourable policy and mechanism for the promotion of renewable energy in irrigation sector to improve the agricultural productivity and production. Solar water pumping technology is one of the emerging technologies to reach to farmers who do not have access to grid electricity and are willing to shift from fossil fuelbased technology to clean energy technology.

In addition to the technical challenge, managerial, aftersale services, etc. are the other challenges. Currently, solar pumping projects are subsidy driven or funded by grants and few projects have mobilized loan to match with grant. Water pumping sector in Nepal is still dominated by diesel 
water pumps followed by electric water pumps [2]. However, the market for solar pump in Nepal is increasing rapidly due to gradual declining in costs and continuous advancement on technology. With an average solar radiation of $4.4 \mathrm{kWh} / \mathrm{m} 2$ to $5.5 \mathrm{kWh} / \mathrm{m} 2 \mathrm{Nepal}$ has a high potential for generating solar power [3]. Despite the claimed benefits of solar pumping technology over conventional type of pumping, solar pumping sector market is surviving as a result of grant or subsidy. With the increase in share of solar pumping technology in the market, various challenges have been observed in the long-term sustainability of the solar pumping technology. Very little study has been carried out to assess the socioeconomic viability of switching from diesel and electric pumps to solar pumps for irrigation purpose, and the sustainability of the technology in long run.

In this context, the objective of this study is to assess and evaluate the cost effectiveness of solar pumping technology over conventional types of pumping system, and understand the perception of users on different business model.

\section{Material and methods}

\subsection{Sample area and size selection}

The sampling area within the study area was carried out using a multi-stage sampling method. For the first stage of sampling, Saptari district was chosen. Spatially it is located between $26^{\circ} 25^{\prime}$ and $26^{\circ} 47^{\prime}$ north latitude, and between $86^{\circ} 28^{\prime}$ to $87^{\circ} 07^{\prime}$ east longitude with altitude range of $61 \mathrm{~m}$ to $610 \mathrm{~m}$. The district lies in Terai region covering an area of $1,363 \mathrm{~km}^{2}$. Out of total $83,240 \mathrm{Ha}$ of arable farm land in the district, only $25,000 \mathrm{Ha}$ has access to irrigation facility [4].
The second phase of sampling was conducted within Saptari district. First of all, an inventory of installed pumps in municipalities and rural municipalities of Saptari district was prepared through secondary data. Focusing on wide geographical coverage within Saptari district, sample area was selected as shown in Figure-1 a.

In the study district, 73 installed solar pumps including sunflower pumps in operation were identified based on the literature review. Sample size were selected based on the number of solar pumps as well as characteristics, which includes: size of system, date of installation, beneficiary HHs number, grid situation, solar vendor, implementing organization, funding agency and major application of water (Irrigation, Livestock, Fishery, and Drinking) as shown in figure $1 \mathrm{~b}$. Based on the information and characteristics, 14 solar pumps were selected by avoiding overlaps/repetition and considering unique characters, geographical proximity, attempting to select as much variety as possible. In addition to Solar/Sunflower pump owners, we also interviewed few diesel pump and electric pump owners, installers, and repair and maintenance (R\&M) service providers of all the pumps.

\section{$2.2 \quad$ Tools development}

Observation checklist was developed to attain quantitative data on the studied pumps. The aim of collecting this information was to compare the performance and efficiency between these pumps.

Alongside quantitative data, qualitative data was retrieved through Key Informant Interview (KII). KII Guidelines were developed to collect qualitative data to: Identify and compare various pumping technologies and business models; Compare performance of solar pump with other

b)

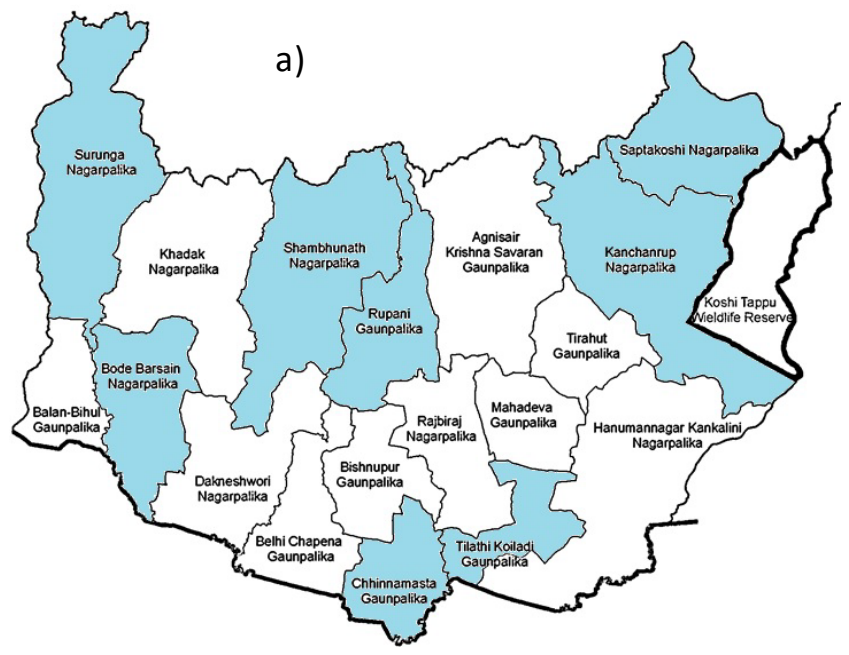

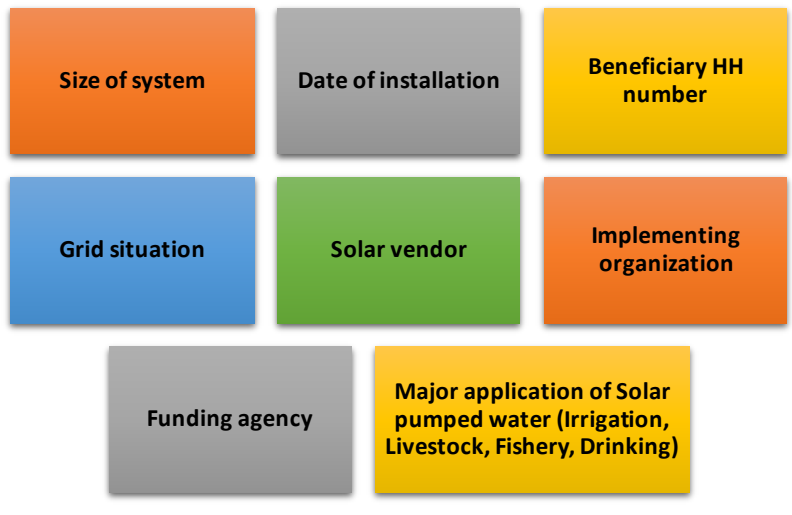

Figure 1: a) Sampled area within study district in filled colour map; b) characteristics included during sample selection 
Table 1: Tools for Data Collection

\begin{tabular}{|l|l|l|l|}
\hline \multicolumn{2}{|l|}{ Tools } & Participants & Remarks \\
\hline Quantitative & $\begin{array}{l}\text { Solar Pumps } \\
\text { Diesel Pumps } \\
\text { Observation } \\
\text { Checklist }\end{array}$ & $\begin{array}{l}\text { Electric Pumps } \\
\text { Sunflower Pumps }\end{array}$ & $\begin{array}{l}\text { Checklist was used to } \\
\text { compare between } \\
\text { different Solar pumping } \\
\text { systems }\end{array}$ \\
\hline \multirow{2}{*}{ Qualitative } & $\begin{array}{l}\text { Key Informant } \\
\text { Interview (KII) } \\
\text { Guidelines }\end{array}$ & $\begin{array}{l}\text { Solar/Sunflower Pump Owners and Operators } \\
\text { Solar/Sunflower Pump Installers and R\&M service providers } \\
\text { Diesel/Electric Pump Owners } \\
\text { Diesel/Electric Pump Suppliers and R\&M service providers }\end{array}$ & \\
\hline
\end{tabular}

conventional pumping systems; Compare different irrigation techniques; Identify perceptions and satisfaction level of pump owners/users in relation to financial, technical, supply-demand, and after-sale services provided by service providers.

Table-1 shows the type of tools used, along with the characteristic of the participants who were interviewed during this study.

\subsection{Data collection and analysis}

Field visit was organized to collect the primary data as well as to enrich and validate the secondary data collected through literature review. Different tools like: KII, FGD, semi structured questionnaire and observation checklist were used to collect the primary data. Observation checklist was mainly focused on technology related data and KII attempted to collect qualitative data based on interaction and in-depth discussion. Alongside, qualitative information received from KIIs was translated before structuring and grouping, to identify recurrent themes and patterns in data.

Semi-structured interviews to key stakeholders comprising solar pump users (13), solar pump suppliers (3), solar pump promotors (4), diesel and electric pump suppliers (4), pump repair and maintenance service centres (2), diesel and electric pump users (10) to identify the determinants for promotion and sustainability of solar pumping system, and impact of solar pumping in agriculture sector. In addition to this, flow rate of each pumps was measured using bucket and stop watch. Stakeholders' perception on different models were assessed through qualitative data analysis approach using data obtained from KII, FGD, and stakeholder interviews.

Quality and consistency of data were checked and segregated for further analysis. The comparative cost for different types of pumping systems were calculated using life cycle cost (LCC) approach over a 20 years period considering initial upfront cost, operating costs, repair and maintenance cost, and replacement cost. To compare the cost effectiveness of different pumping technologies, most commonly used solar pumping unit (1200 Wp, 1.5 HP Pump, 5m lift height) was considered for the analysis. LCC were calculated for different capacity utilization factors (CUFs). Unit water cost (UWC) was calculated considering different CUFs. Similarly, UWC for diesel powered pump and grid operated electric pump was calculated to deliver the same volume of water over 20 year time span. Diesel pump set (5 HP) and electric pump set (1.5 HP) were considered for cost analysis since those size of the pump sets was found to be the most common one to irrigate the agricultural land in this area.

\section{$3 \quad$ Findings and discussions}

\subsection{Characteristics of solar pumped irrigation system}

Nepal having good solar energy potential with an average of more than 300 sunny days per year and average solar radiation of $4.4 \mathrm{kWh} / \mathrm{m}^{2} /$ day to $5.5 \mathrm{kWh} / \mathrm{m}^{2} /$ day [3]. Subsidy policy, 2009 introduced subsidy in solar pumping for drinking and micro-irrigation and enriched by recent renewable energy subsidy policy 2016 with provision of solar pumping system for irrigation [5]. Alternate Energy Promotion Center (AEPC), GoN, has already supported around 200 solar pumped irrigation system (SPIS) [6]. In addition to government programs, non-government organizations are also promoting solar pumping technology by mobilizing grant and credits. However, subsidy or grant are provided mainly for purchasing the capital equipment to improve access to water for irrigation purpose in study area.

The average ground water table ranges of $5 \mathrm{~m}-15 \mathrm{~m}$ and average solar radiation of $4.5 \mathrm{kWh} / \mathrm{m} 2 /$ day in the study district [6]. The business model of the promotor as well as the availability of the size in the market guided the system 
size of SPIP. Size of solar pumping system were found in the range of $80 \mathrm{Wp}$ (Watt peak) to $2400 \mathrm{Wp}$, with 1200 $\mathrm{Wp}$ system as the most commonly used with $1.5 \mathrm{HP}$ submersible AC pump. Size of single PV module was in the range of $80 \mathrm{Wp}$ to $300 \mathrm{Wp}$. Among the surveyed 14 pumps, number AC pumps (9 sets) were more than DC pumps ( 5 sets), AC pumps were used in bigger size of systems. Similarly, 57\% pumps were surfaced mounted. Submersible pumps were installed in those areas' groundwater table is high.

None of the solar pumping system had the provision of battery in sampled sites. Storage tanks were provided only in two sites where the water was pumped for the purpose of drinking and sanitation. Out of 14 pumping sites visited, 10 units were for irrigation purpose. Similarly, 2 units were used for fish farming and the other 2 units were used to supply water in institutions (Madrassa and Temple) for drinking and sanitation purpose. Around 50\% farmers were found producing traditional crops using solar powered water pump. Around 30\% farmers are using furrow irrigation method, whereas $20 \%$ are using drip, and rest of $50 \%$ are using either free flooding or basin irrigation. To maximize the benefits of solar pump, it is necessary to facilitate community to adopt cash crops by replacing traditional crops, optimize cropping patterns to maximize the use of the solar pump, and promote microirrigation technology such as drip, micro-sprinkler, etc. to optimize the water use.

\subsection{Cost effectiveness for different pumping technologies}

Figure-2 and Table-2 show the cost per unit water for three different pumping technologies in different scenario. If solar pump is operated utilizing only $10 \%$ of its capacity, the per unit water cost is NPR 24.4 , and the cost is reduced to NPR 2.83 if it is operated at $90 \%$ CUF. The reason behind this is that the high upfront cost of solar pump and minimal operation and maintenance cost. But on the other hand, operation cost increases with increase in operation hours in diesel and electric pump. The cost is reduced rapidly with increase in operating hours in solar pump whereas the curves are almost flat in diesel and electric pump. The graph shows that when solar pump is operated at more than $45 \%$ CUF, solar pumps become cost effective option compared to diesel pump. If solar pump is operated at more than $90 \%$ CUF, solar pump becomes cost effective solution than electric pump.

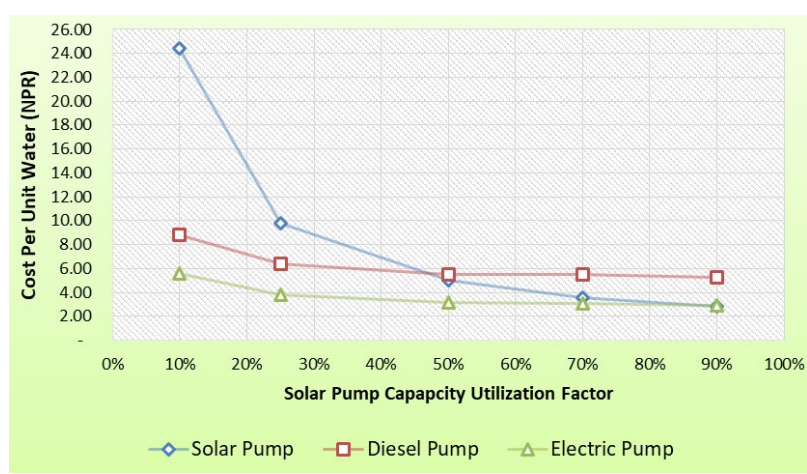

Figure 2: Cost per Unit Water in Different Pumping Technologies

Table 2: Cost per Unit Water in Different Pumping Technologies

\begin{tabular}{|l|l|l|l|l|}
\hline Solar & \multirow{2}{*}{$\begin{array}{l}\text { Wump } \\
\text { CUF }\end{array}$} & $\begin{array}{l}\text { Volume } \\
\left(\mathbf{m}^{\mathbf{3}} / \mathbf{d a y}\right)\end{array}$ & \multicolumn{3}{|l|}{ Cost Per Unit Water $\left(\right.$ Rs. $\left./ \mathbf{m}^{\mathbf{3}}\right)$} \\
\cline { 3 - 5 } & $\begin{array}{l}\text { Solar } \\
\text { Pump }\end{array}$ & $\begin{array}{l}\text { Diesel } \\
\text { Pump }\end{array}$ & $\begin{array}{l}\text { Electric } \\
\text { Pump }\end{array}$ \\
\hline $90 \%$ & 55.4 & 2.83 & 5.26 & 2.9 \\
\hline $70 \%$ & 43.09 & 3.6 & 5.48 & 3.06 \\
\hline $50 \%$ & 30.78 & 5 & 5.51 & 3.14 \\
\hline $25 \%$ & 15.39 & 9.8 & 6.39 & 3.81 \\
\hline $10 \%$ & 6.16 & 24.4 & 8.8 & 5.58 \\
\hline
\end{tabular}

\subsection{Payback period for solar pumps}

Solar pumps are found cost-effective solution if they are operated for longer period. The payback period of solar pump is calculated at different scenarios using sensitivity analysis of solar pump at $70 \%$ and $90 \%$ CUFs and comparing with diesel pumps. If a diesel pump is operated to supply water equivalent to water volume pumped by solar pump at $50 \%$ CUF, cost per unit water to be pumped

Table 3: Payback Period (yrs.) for Solar Pump at Different Unit Price of Water

\begin{tabular}{|l|l|l|l|l|}
\hline \multicolumn{2}{|l|}{ Price of Water (NPR/unit) $\rightarrow$} & $\mathbf{5 . 5 1}$ & $\mathbf{7 . 9 2}$ & $\mathbf{1 0}$ \\
\hline Solar Pump (CUF) $\downarrow$ & $\begin{array}{l}\text { Average Daily } \\
\text { Water (m } \mathbf{m} / \text { day) }\end{array}$ & $\begin{array}{l}\text { Minimum price of water } \\
\text { for diesel pump set* }\end{array}$ & $\begin{array}{l}\text { Prevailing rate of water } \\
\text { from diesel pump set }\end{array}$ & $\begin{array}{l}\text { Community's Desire } \\
\text { to pay for water }\end{array}$ \\
\hline $90 \%$ & 55 & 4.79 & 3.08 & 2.37 \\
\hline $70 \%$ & 43 & 6.97 & 4.18 & 3.14 \\
\hline $50 \%$ & 31 & $>20$ yrs & 6.9 & 4.76 \\
\hline $25 \%$ & 15 & - & $>20$ yrs & 18.66 \\
\hline $10 \%$ & 6 & - & - & $>20$ yrs \\
\hline
\end{tabular}

* if operated equivalent to $50 \%$ CUF solar pump 
from diesel pump set is NPR 5.51. If we consider this price as a tariff rate per unit water, the payback period for solar system will be 6.97 years, if the solar system is operated at $70 \%$ CUF. If solar pump is operated at less than $50 \%$ CUF, solar pump entrepreneur will not be able to recover his/her investment in entire project life at this tariff rate.

Currently farmers are paying NPR 7.92 per unit water to diesel pump owner where farmers are buying water for irrigation from diesel pump set. If we consider this price as a tariff rate per unit water, payback period for solar pumping system is 4.18 years, if solar pump is operated at $70 \%$ CUF.

Farmers mentioned that they are happy to pay up to NPR 10 per unit water if they get water on demand. If we consider this price of water as tariff rate, payback period for solar pumping system will be 3.14 years, if solar pump is operated at $70 \%$ CUF.

\subsection{Economic impact on agricultural system}

It is too early to define the benefits received by the farmers from solar pumping system and needs to be matured enough to see how farmers will reap the full benefits of solar pumping system during its life time. However, we were able to observe and record some of the tangible benefits received by the farmers in the field and interviewed some farmers to understand the impact of solar pump from their point of view.

In our study, we found that $50 \%$ of the farmers, who were dependent mainly on rain fed irrigation and produced only single crop (rice) in a year, have increased their crop intensity from $100 \%$ to $300 \%$ after solar pump installation. It has been claimed by farmers that the crop productivity has increased by around $15 \%$ after solar pump installation. However, there was no quantitative data available to validate this information. According to the farmers, the use of diesel pumping set has reduced drastically. 10 out of $12,83 \%$ farmers reported that they use diesel pump set around 2 times in a year: i) when they need large flow of water during paddy plantation, ii) to irrigate wheat field/vegetable field during winter. The reduction in use of diesel pump throughout the year significantly reduces the input cost for irrigation.

\subsection{Perception on different business model}

Three types of finance/ business models were observed to promote solar pumping technology in Saptari district namely subsidy/grant model, grant cum loan model, and rent to own model. Around $50 \%$ of the sampled solar plants in Saptari district were implemented through 100\% grant. Remaining $50 \%$ were having mix financing model: $60 \%$ subsidy and $40 \%$ equity investment. In Grant cum Loan Model, $60 \%$ upfront cost of the solar pumping system was covered by grant, $20 \%$ upfront cost from farmer as an equity and project provided loan for $20 \%$ of the upfront cost @ 5\% interest for 3 years period of time. In Rent-to-Own model, project invested $100 \%$ of the upfront cost and installed the technology for farmers. Farmer is entitled for $60 \%$ of the investment as subsidy and $40 \%$ as loan. There will be no upfront cost required for farmer to purchase the technology. Interest rate for loan is @ $5 \%$ and loan recovery period is 3 years. Farmer will own the pump after $100 \%$ loan repayment.

Current pump users from sampled plants are relatively affluent farmers with more land, better access to irrigation and have alternatives (diesel or electric pump) for irrigation. Average land holding of the farmers who purchased the technology in mix financing model (grant and loan) is in the range of 3 to 4 bigha $(2.03$ to $2.7 \mathrm{Ha}$ ). Different study reveals that only affluent farmers are able to purchase the technology as the subsidy and delivery mechanism are not found very supportive to smallholders. Hence, favorable environment to access finance is required for solar pumps to be a choice of pumping technology for many smallholder farmers in the future.

Without investment from private sector into this business, solar pumping sector cannot be shifted from subsidy/grant driven to commercially driven. But, there are still many challenges to attract the private sector into this business. The biggest concern for private sector is their investment security, followed by the return on its investment compared to other alternative investment opportunities. Furthermore, as the target client are smallholder farmers living below the poverty line, the perceived risk of payment default is higher, which could make the investors wary. There needs to be more incentives to attract private developers into this business in addition to subsidy. Provision of low interest rate on loan; collateral free debt finance; exemption on taxes and import duties on equipment needed for RE projects are some such incentives that could help to attract private sectors and accelerate the market of solar pumping systems.

\subsection{Satisfaction and Perception on different water use technologies}

Users' perceptions and experiences on solar, diesel and electric pump sets were gathered through interviews. Issues that were raised for solar pump were: high capital cost, lack of spare parts and maintenance center at local 
market, long response time from service providers, limited working hours, less discharge and unable to supply variations in water demand, chances of PV module damage/or stolen etc. The perceived benefits were: no fuel cost, automatic in operation system, no pollution, no need to transport pump set which makes life of women and children easy.

The weight of even small diesel pump (5 HP) is heavy, around $60-70 \mathrm{~kg}$ and is difficult for women and children to take to field and bring it back to home every time. Big solar plants are fixed at site with fencing and anti- theft bolt, and smaller solar pump set (sunflower pump) are portable and very light, as well as easy to transport.

\section{Conclusions}

Fossil fuel-based pumping technologies are still an attractive option to those farmers who are producing traditional crops and utilization of the pumping equipment is for short period. Effective supply chain network, easy access to repairing services, low capital cost etc. are also making fossil fuel-based pumping technologies as the first choice of farmers.

It seems that farmers adopted solar pumping system as a supplementary to conventional pumps. Fully granted or subsidized price of the system somehow motivated farmers to install the technology. Diesel/electric pumps are not completely replaced by solar pumps. However, the use of diesel/electric pump has been greatly reduced and tangible benefits can be seen.

High upfront cost of solar powered system seems hindering to popularize and flourish the system among the smallholder farmers. Subsidy and delivery mechanism are not found very supportive to smallholders. With better access to finance, technology and services, solar pumps might become the first choice for smallholders in the future.

Low utilization factor of solar pumps is found to be one of the challenges. Cost per unit water becomes cheaper when the CUF of solar pump increases. In general, Solar pumps needs to be operated at least $700 \mathrm{hrs}$ per year (43\% CUF) to compete with diesel pump. Grid operated electric pump is found to be more cost-effective technology over the other two diesel and solar pumps. However, if solar pumps are operated at $90 \%$ CUF, solar pumps come out to be cost effective than grid electric pump.

Considering the rental charge of diesel pump set and operation cost, the cost per unit water was found as NPR $7.92 / \mathrm{m} 3$. Payback period of Solar Pumping system will be 4 years when cost per unit water price is set as same to rented diesel pump set, and the solar pump is operated at $70 \%$ CUF.

\section{Acknowledgment}

We are very much thankful to Ram C. Bastakoti, for their continuous support for carrying out the field activities. We highly appreciate the Groundwater Resources Development Board (GWRDB), Alternate Energy Promotion Centre (AEPC) for providing support during the study. Lastly, we express our sincere gratitude to the Australian Centre for International Agriculture research (ACIAR) for providing the funding to carry out the project on improving dry season irrigation for marginal and tenant farmers in the Eastern Gangetic Plains through which this study was implemented.

\section{References}

[1] R. Foster and A. Cota, "Solar water pumping advances and comparative economics," ELSEVIER, pp. 1431-1436, 2014.

[2] Consolidated Management Services Nepal Pvt. Ltd., "Nepal's Energy Sector Vision 2050 AD," Water and Energy Commission Secretariat, GoN, Kathmandu, 2013.

[3] Solargis, "Solar Resource and Photovoltaic Potential of Nepal," World Bank Group (ESMAP), 2017.

[4] NEEDS, "District climate and Energy Plan (Saptari)," Alternative Energy Promotion Centre (AEPC), Nepal, 2017.

[5] Ministry of Population and Environment, "Renewable Energy Subsidy Policy, 2073 BS," Ministry of Population and Environment, GoN, Kathmandu, 2016.

[6] R. Dhital, "Solar Pumping Experience in Nepal," in Asia Clean Energy Forum 2018, Manila, Philippines, 2018. 